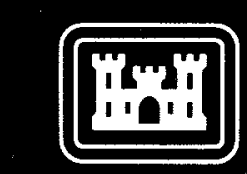

US Army Corps

of Engineers
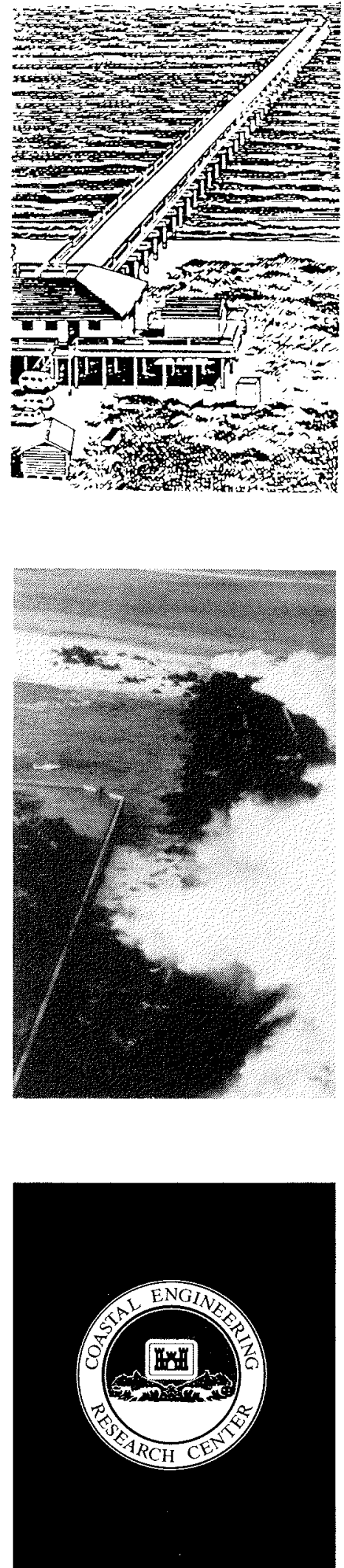

\section{PREDICTION OF OVERTOPPING RATES FOR IRREGULAR WAVES ON RIPRAP REVETMENTS}

\author{
by
}

Donald L. Ward

Coastal Engineering Research Center

DEPARTMENT OF THE ARMY

Waterways Experiment Station, Corps of Engineers

3909 Halls Ferry Road, Vicksburg, Mississippi 39180-6199

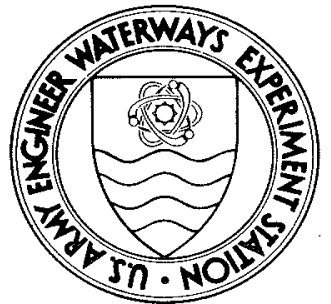

April 1992

Final Report

Approved For Public Release; Distribution Is Unlimited

Prepared for DEPARTMENT OF THE ARMY

US Army Corps of Engineers

Washington, DC 20314-1000 
Destroy this report when no longer needed. Do not return it to the originator.

The findings in this report are not to be construed as an official Department of the Army position unless so designated by other authorized documents.

The contents of this report are not to be used for advertising, publication, or promotional purposes. Citation of trade names does not constitute an official endorsement or approval of the use of such commercial products. 


\begin{tabular}{|c|c|c|c|c|c|}
\hline \multicolumn{4}{|c|}{ REPORT DOCUMENTATION PAGE } & \multicolumn{2}{|r|}{$\begin{array}{l}\text { Form Approved } \\
\text { OMB No. } 0704-0188\end{array}$} \\
\hline \multicolumn{6}{|c|}{ 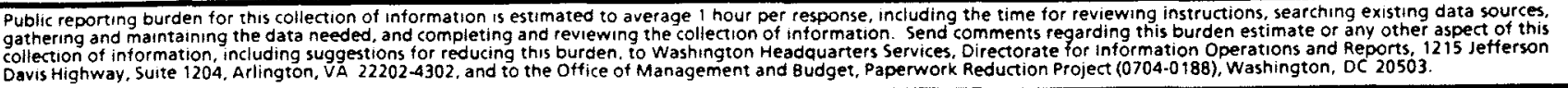 } \\
\hline \multicolumn{2}{|c|}{ 1. AGENCY USE ONLY (Leave blank) } & $\begin{array}{l}\text { 2. REPORT DATE } \\
\text { April } 1992 \\
\end{array}$ & \multicolumn{3}{|c|}{$\begin{array}{l}\text { 3. REPORT TYPE AND DATES COVERED } \\
\text { Final report }\end{array}$} \\
\hline \multicolumn{3}{|c|}{$\begin{array}{l}\text { 4. MTLE AND SUBTITLE } \\
\text { Prediction of Overtopping Rates for Irregular } \\
\text { Waves on Riprap Revetments }\end{array}$} & & \multicolumn{2}{|c|}{ 5. FUNDING NUMBERS } \\
\hline \multicolumn{4}{|l|}{$\begin{array}{l}\text { 6. AUTHOR(S) } \\
\text { Donald L. Ward }\end{array}$} & & \\
\hline \multicolumn{4}{|c|}{$\begin{array}{l}\text { 7. PERFORMING ORGANIZATION NAME(S) AND ADDRESS(ES) } \\
\text { USAE Waterways Experiment Station } \\
\text { Coastal Engineering Research Center } \\
\text { 3909 Halls Ferry Road, Vicksburg, MS 39180-6199 }\end{array}$} & \multicolumn{2}{|c|}{$\begin{array}{l}\text { 8. PERFORMING ORGANIZATION } \\
\text { REPORT NUMBER } \\
\text { Miscellaneous Paper } \\
\text { CERC-92-4 }\end{array}$} \\
\hline \multicolumn{4}{|c|}{$\begin{array}{l}\text { 9. SPONSORING /MONITORING AGENCY NAME(S) AND ADDRESS(ES) } \\
\text { US Army Corps of Engineers } \\
\text { Washington, DC 20314-1000 }\end{array}$} & \multicolumn{2}{|c|}{$\begin{array}{l}\text { 10. SPONSORING/MONITORING } \\
\text { AGENCY REPORT NUMBER }\end{array}$} \\
\hline \multicolumn{6}{|c|}{$\begin{array}{l}\text { 11. SUPPLEMENTARY NOTES } \\
\text { Available from National Technical Information Service, } 5285 \text { Port Royal Road } \\
\text { Springfield, VA } 22161 .\end{array}$} \\
\hline \multicolumn{4}{|c|}{$\begin{array}{l}\text { 12a. DISTRIBUTION/AVAILABILITY STATEMENT } \\
\text { Approved for public release; distribution is unlimited. }\end{array}$} & \multicolumn{2}{|c|}{ 12b. DISTRIBUTION CODE } \\
\hline \multicolumn{6}{|c|}{ 13. ABSTRACT (Maximum 200 words) } \\
\hline \multicolumn{6}{|c|}{$\begin{array}{l}\text { Present methods of predicting wave overtopping on revetments are limited, and determining } \\
\text { what data are available requires extensive interpolation and/or extrapolation of monochromatic wave } \\
\text { conditions. } \\
\text { Physical model tests were conducted to measure wave overtopping rates occurring on a } 1: 2 \text { and } \\
\text { 1:3.5 stone revetment slope. The tests cover a range of incident irregular wave conditions using a } \\
\text { foreslope of } 1: 100 \text {. } \\
\text { Results of the tests are expressed in terms of overtopping rate per length of structure versus } \\
\text { relative freeboard. Relative freeboard is particularly effective, as it accounts for different water } \\
\text { levels in the freeboard, wave heights in } \mathrm{H}_{\text {mo }} \text {, and wave periods in } \mathrm{L}_{\mathrm{o}} \text {. }\end{array}$} \\
\hline 14. SUBJECT TERMS & Run & & & & $\begin{array}{l}\text { 15. NUMBER OF PAGES } \\
20\end{array}$ \\
\hline $\begin{array}{l}\text { Revetment } \\
\text { Riprap }\end{array}$ & Wav & evertopping & & & 16. PRICE CODE \\
\hline $\begin{array}{l}\text { 17. SECURITY CLASSIFICATION } \\
\text { OF REPORT } \\
\text { UNCLASSIFIED }\end{array}$ & 18. & $\begin{array}{l}\text { ECURITY CLASSIFICATION } \\
\text { F THIS PAGE } \\
\text { UNCLASSIFIED }\end{array}$ & $\begin{array}{l}\text { 19. SE } \\
\text { OF }\end{array}$ & ATION & 20. LIMITATION OF ABSTRACT \\
\hline
\end{tabular}




\section{$\underline{\text { Preface }}$}

The investigation described in this report was authorized as a part of the Civil Works Research and Development Program by Headquarters, US Army Corps of Engineers (HQUSACE). Work was performed under Work Unit 32432 , "Design of Revetments and Seawalls," at the Coastal Engineering Research Center (CERC), US Army Engineer Waterways Experiment Station (WES). Messrs. John H. Lockhart, Jr., and John G. Housley were HQUSACE Technical Monitors. Dr. C. Linwood Vincent was CERC Program Manager.

The study was conducted by personnel of CERC under the general direction of Dr. James R. Houston, Director, CERC, and Mr. Charles C. Calhoun, Jr., Assistant Director, CERC. Direct supervision was provided by Messrs. C. E. Chatham, Chief, Wave Dynamics Division, and D. Donald Davidson, Chief, Wave Research Branch (WRB). This report was prepared by Mr. Donald L. Ward, Principal Investigator, WRB. The models were operated by Messrs. Willie G. Dubose and John M. Heggins, WRB. This report was typed by Ms. Myra E. Willis, WRB, and edited by Ms. Janean Shirley, Information Technology Laboratory, WES. At the time of publication of this report, Director of WES was Dr. Robert W. Whalin. Commander and Deputy Director was COL Leonard G. Hasse11, EN. 


\section{Contents}

\section{Preface}

Conversion Factors, Non-SI to SI (Metric) Units of Measurement.

Introduction .

Purpose of Study

Test Facility.

Test Structur

Results

Conclusions.

APPENDIX A: EXAMPLE PROBLEM.

APPENDIX B: NOTATION 
Conversion Factors, Non-SI To SI (Metric)

Units of Measurement

\begin{tabular}{|c|c|c|}
\hline Multiply & By & To Obtain \\
\hline $\begin{array}{l}\text { cubic feet } \\
\text { per second }\end{array}$ & 0.02831685 & cubic metres \\
\hline feet & 0.3048 & metres \\
\hline $\begin{array}{l}\text { gallons (US liquid) } \\
\text { per hour }\end{array}$ & 3.785412 & cubic decimetres \\
\hline pounds (mass) & 0.4535924 & kilograms \\
\hline ounces & 28.35 & grams \\
\hline $\begin{array}{l}\text { pounds (mass) per } \\
\text { cubic foot }\end{array}$ & 16.01846 & $\begin{array}{l}\text { kilograms per } \\
\text { cubic metre }\end{array}$ \\
\hline
\end{tabular}




\section{PREDICTION OF OVERTOPPING RATES}

FOR IRREGULAR WAVES ON RIPRAP REVETMENTS

\section{Introduction}

1. Design of coastal revetments typically assumes that the structure will be of sufficient height to prevent overtopping. This is not always economically feasible, however, and changing conditions have rendered many existing structures inadequate. Due to the potential for substantial damage by overtopping, it is vital that design engineers be able to accurately predict overtopping rates.

2. Most available literature on overtopping of riprap revetments is based on monochromatic waves. Attempting to apply this information to the irregular wave conditions found in nature is difficult. For example, Tsuruta and Goda (1968) cite an experiment where overtopping rates for irregular waves were compared to those for monochromatic waves. In this case, the monochromatic wave height was equal to the significant wave height $\left(H_{s}\right)^{\text {* }}$ of the irregular wave train. For this particular set of tests, at $H_{s}=14.5 \mathrm{~cm}$, the overtopping rate for monochromatic waves was up to five times that of irregular waves, overtopping rates were equal at $H_{s}=10.5 \mathrm{~cm}$, and overtopping rates for irregular waves were higher than monochromatic waves if the significant wave height was further reduced.

3. Unless the revetment crest is located at the still-water level (swl), not all waves in an irregular wave train will overtop the revetment. Thus, the freeboard has an obvious effect on dictating the portion of the incident wave spectrum that will cause overtopping. This is complicated by damping effects of filter layers and riprap, and by interactions of wave runup and rundown. Other factors affecting overtopping are structure slope, porosity, and roughness; depth of structure and offshore slope; wave spectral characteristics of peak period, height of zeroth moment, and spectral width; and wind characteristics of speed, direction, and duration.

4. Both the Shore Protection Manual (SPM) (1984) and the Automated

* For convenience, symbols and abbreviations are listed in the Notation (Appendix B). 
Coastal Engineering System (ACES) (1990) recommend a method developed by Weggel (1976) for monochromatic waves to determine overtopping rates. To apply this method to irregular waves, a Rayleigh distribution is assumed and the distribution is divided into discrete segments. The overtopping contribution from each segment is determined and summed to yield the total overtopping rate. Weggel's method requires that two parameters be determined from charts published in the SPM; these values then are entered into the overtopping equation. For irregular waves, the assumption is made that values obtained from the charts for significant wave height and peak period are constant for all segments of the distribution. Charts are published in the SPM for a number of coastal structures including revetments, breakwaters, and seawalls, but the only chart for riprap revetments is for a $1: 1.5(\mathrm{~V}: \mathrm{H})$ slope, and the number of data points is very limited. Thus, extensive interpolation and/or extrapolation is required even for monochromatic wave conditions, and results are even more questionable when applied to irregular wave conditions.

\section{Purpose of Study}

5. Improved design guidance for overtopping of coastal revetments is needed. Therefore a series of physical model tests was conducted at the US Army Engineer Waterways Experiment Station's Coastal Engineering Research Center to measure overtopping rates for a range of incident irregular wave conditions on model revetments. The purpose of the study was to develop design criteria for predicting overtopping rates on riprap revetments under irregular wave conditions.

\section{Test Facility}

6. All tests were conducted in a $3.0-\mathrm{ftx}$-wide by $150 \mathrm{ft}-\mathrm{fong}$ by $3.0 \mathrm{ft}$ deep wave flume (Figure 1). A 1:20 slope was installed in the bottom of the flume starting $36.5 \mathrm{ft}$ from the wave board and extending for $10 \mathrm{ft}$, followed by a $1: 100$ slope extending to the test structure.

7. The flume was divided lengthwise into two $1.5-\mathrm{ft}$-wide channels

* A table of factors for converting non-SI units of measurement to SI units is presented on page 3. 


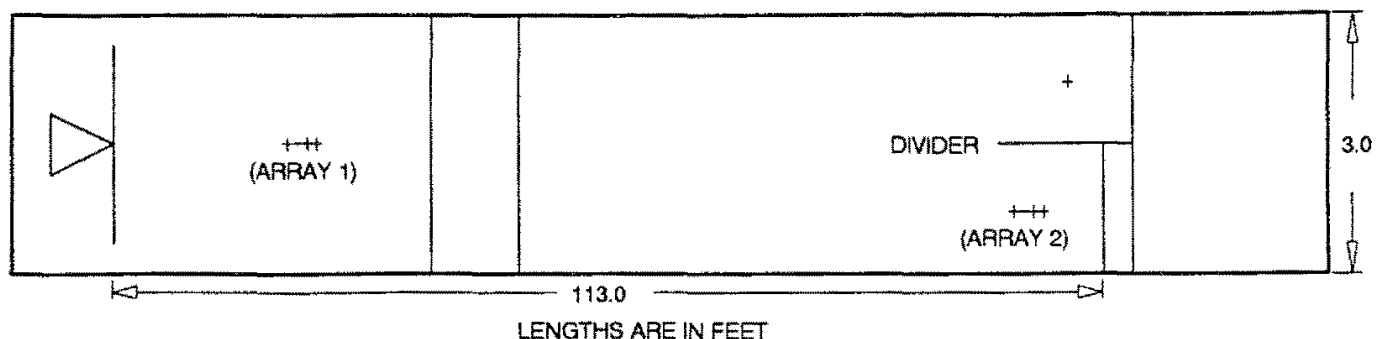

+ WAVE GaUge WAVE GaUge arRay

DISTORTED SCALE: $1 \mathrm{~V}=10 \mathrm{H}$

TOP VIEW

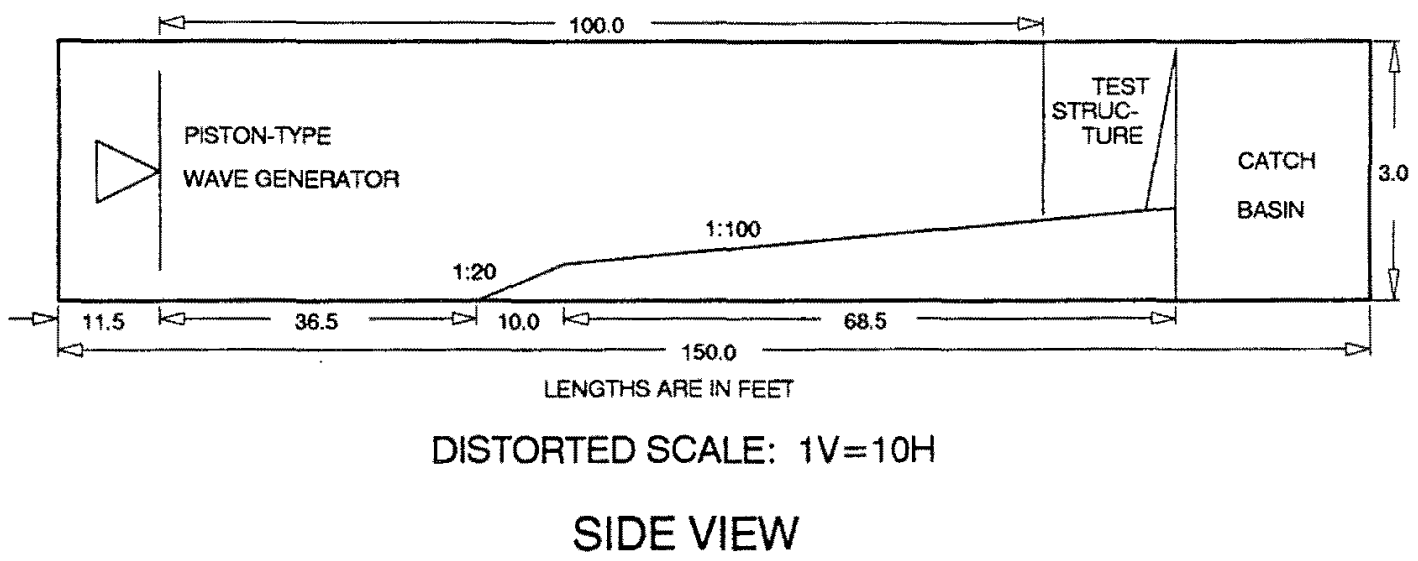

Figure 1. Plan and profile views of wave flume 
starting $100.0 \mathrm{ft}$ from the wave board and extending past the structure. A wave absorber was placed in one channel, while the structure was placed in the other channel, thus minimizing reflection in the flume. An array of three wave gages was centered $21.5 \mathrm{ft}$ in front of the wave board to monitor the generated signal. A similar array was placed in the side of the flume with the test structure, centered $104.5 \mathrm{ft}$ from the wave board, to be used in separating the incident and reflected wave trains. Wire resistance staff gages were read at $10 \mathrm{~Hz}$ to monitor the water surface elevation.

8. A piston-type wave generator powered by an electro-hydraulic pump and controlled by a computer-generated signal was used to produce the waves.

\section{Test Structure}

9. Test structures modeled $1: 2$ and $1: 3.5$ slopes of an impervious substratum, protected by a filter layer and a layer of riprap (Figure 2). Sand was glued to a plywood board to provide the necessary roughness, and the board was installed in the flume to represent the existing slope. A 0.07 -ftthick layer of crushed stone averaging $0.04 \mathrm{oz}$ was used for the filter layer. The armor layer was 0.26 -ft thick and was constructed of crushed limestone with a specific gravity of 2.67 , a blocky to angular shape, and a gradation of

$$
\frac{D_{85}}{D_{15}}=1.79
$$

where $D_{85}$ and $D_{15}$ are the 85-percentile and 15-percentile diameters, respectively. All armor stones fell within the range

$$
\frac{1}{8}\left(W_{50}\right)<w<4\left(W_{50}\right)
$$

where $W_{50}$ is the median stone weight and $W$ is the weight of an individual armor stone.

10. Riprap is commonly sized by either $W_{50}$ or by nominal diameter, $\left(D_{n}\right)_{50}$. The armor layer stone used in these tests had a $W_{50}$ of $0.22 \mathrm{lb}$ and a $\left(D_{n}\right)_{s o}$ of $0.11 \mathrm{ft}$. Based on a slope of $1: 2$ and a riprap stability coefficient ( $K_{R R}$ ) of 2.2 (SPM 1984) in Hudson's equation (Hudson and Jackson 1962), this corresponds to a design wave height of $0.30 \mathrm{ft}$. Hudson's equation is given as 


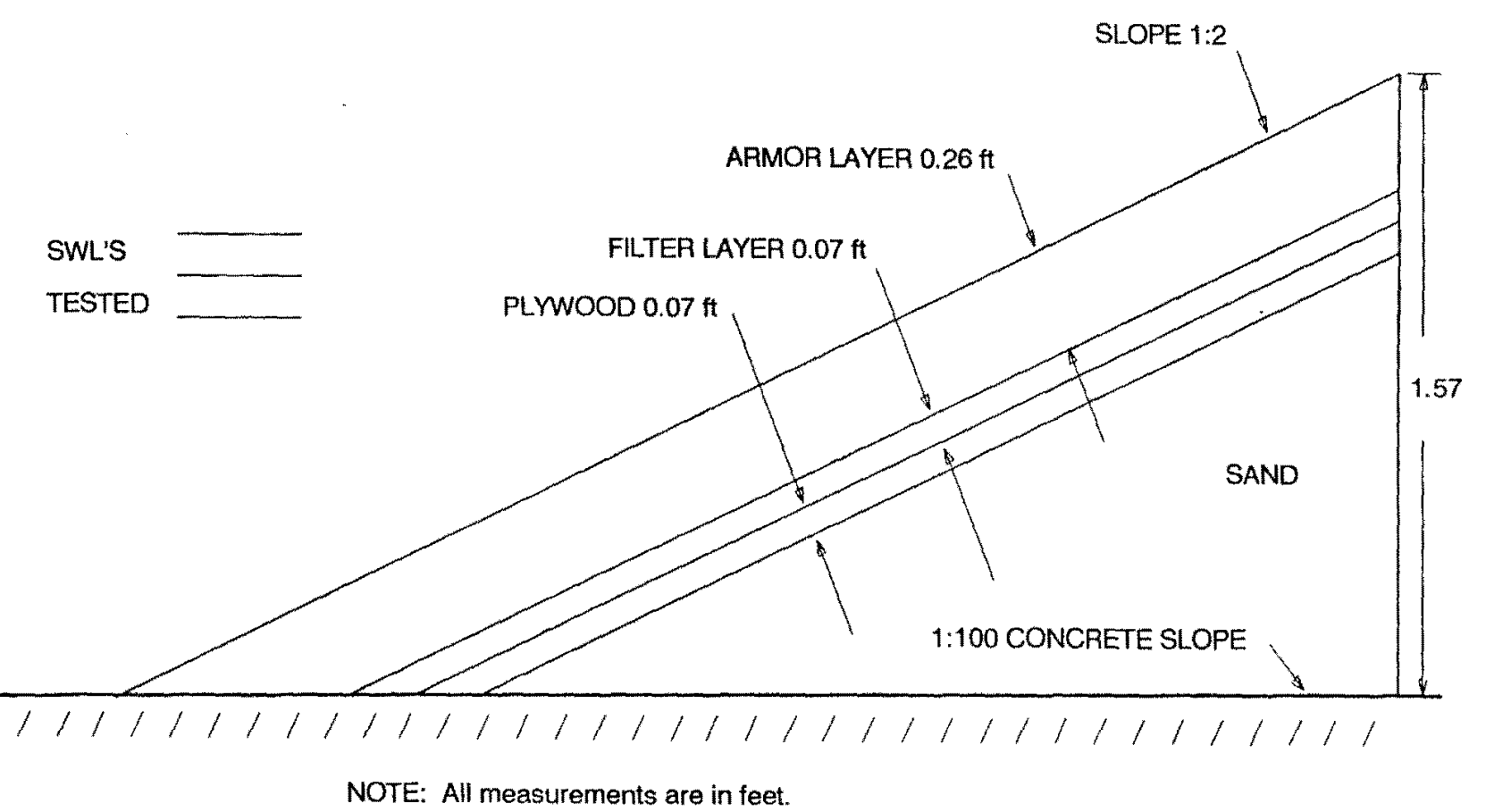

Figure 2. Cross section of model revetment for $1: 2$ slope 


$$
W_{50}=\frac{W_{Y} H^{3}}{K_{R R}\left(S_{I}-1\right)^{3} \cot \theta}
$$

where $w_{r}$ is the specific weight of rock, $H$ is a monochromatic wave height, $K_{R R}$ is a stability coefficient, $S_{r}$ is the relative specific gravity defined as specific weight of armor stone $\left(w_{r}\right)$ divided by specific weight of fresh water $\left(w_{w}\right)$, and $\cot \theta$ is the cotangent of the revetment slope. Specific weights of the model stone and water were 167 pcf and 62.4 pcf, respectively. For irregular wave tests, design is based on the average of the highest 10 percent of waves $\left(\mathrm{H}_{10}\right)$. Assuming a Rayleigh distribution, the design $\mathrm{H}_{10}$ of $0.3 \mathrm{ft}$ corresponds to an $\mathrm{H}_{\mathrm{mo}}$ (wave height of the zeroth moment) of about $0.24 \mathrm{ft}$.

11. The filter and armor stone layers were placed by dumping from a small shovel in a manner to simulate prototype construction by an experienced coastal contractor. The toe of the structure was $113 \mathrm{ft}$ from the wave board for the $1: 2$ slope, and $110 \mathrm{ft}$ from the wave board for the 1:3.5 slope.

\section{$\underline{\text { Results }}$}

12. Results of the tests are listed in Tables 1 through 3. Tables 1 and 2 list wave conditions, runup, and overtopping data for tests on $1: 2$ and $1: 3.5$ revetments, respectively, while Table 3 lists only those tests where overtopping occurred. Data in Tables 1 and 2 are provided for information that may be of value to the engineer; the discussion that follows is based on the data in Table 3 .

13. As evidenced in the tables, tests were conducted at a range of water levels, wave heights, and wave periods for each of the two slopes. A major difficulty was determining a means of graphically presenting this information in a meaningful format. For this purpose, the relative freeboard parameter of Ahrens and Heimbaugh (1988) was selected. Relative freeboard is defined as

$$
\mathrm{F}^{\prime}=\frac{\mathrm{F}}{\left(H_{m o}^{2} \mathrm{~L}_{0}\right)^{1 / 3}}
$$

where $F^{\prime}$ is relative freeboard, $F$ is freeboard (height of structure crest above SwI), and $L_{o}$ is deepwater wavelength. This parameter is particularly 
Table 1

Wave Condition, Runup, and Overtopping Data for Tests with a 1:2 Slope

\begin{tabular}{|c|c|c|c|c|c|c|c|c|c|c|}
\hline $\begin{array}{l}\text { Test } \\
\text { No. }\end{array}$ & $\begin{array}{l}\text { Array } 1 \\
\text { Wave } \\
\text { Period } \\
\mathrm{T}_{\mathrm{p}}(1) \\
\text { sec }\end{array}$ & $\begin{array}{l}\text { Array } 1 \\
\text { Wave } \\
\text { Height } \\
\mathrm{H}_{\text {mo }}(1) \\
\text { ft }\end{array}$ & $\begin{array}{l}\text { Array } 2 \\
\text { Reflection } \\
\text { Coefficient } \\
\mathrm{K}_{\mathrm{r}}(2)\end{array}$ & $\begin{array}{l}\text { Array } 2 \\
\text { Wave } \\
\text { Period } \\
\mathrm{T}_{\mathrm{p}}(2) \\
\text { sec }\end{array}$ & $\begin{array}{l}\text { Array } 2 \\
\text { Wave } \\
\text { Height } \\
\mathrm{H}_{\text {mo }}(2) \\
\text { ft }\end{array}$ & $\begin{array}{l}\text { Average } \\
\text { SwL } \\
\text { Depth } \\
\text { h } \\
\text { ft }\end{array}$ & $\begin{array}{l}\text { Depth } \\
\text { at } \\
\text { Toe } \\
d_{s} \\
\text { ft }\end{array}$ & $\begin{array}{c}\text { Freeboard } \\
\text { F } \\
\text { ft }\end{array}$ & $\begin{array}{l}\text { Upper } \\
\text { Limit of } \\
\text { Runup } \\
\mathrm{R}_{\max } \\
\mathrm{ft}\end{array}$ & $\begin{array}{c}\text { Overtopping } \\
\text { Rate } \\
Q \\
\text { cfs/ft } \\
\end{array}$ \\
\hline 1 & 1.250 & 0.156 & 0.278 & 1.175 & 0.140 & 2.300 & 0.961 & 0.658 & 0.095 & 0.0000 \\
\hline 2 & 1.250 & 0.305 & 0.251 & 1.178 & 0.274 & 2.300 & 0.961 & 0.658 & 0.290 & 0.0000 \\
\hline 3 & 2.281 & 0.257 & 0.624 & 2.281 & 0.359 & 2.300 & 0.961 & 0.658 & 0.529 & 0.0000 \\
\hline 4 & 2.978 & 0.339 & 0.600 & 3.615 & 0.462 & 2.292 & 0.953 & 0.667 & NA & 0.0011 \\
\hline 5 & 2. 281 & 0.343 & 0.600 & 2.299 & 0.463 & 2.296 & 0.957 & 0.662 & NA & 0.0002 \\
\hline 6 & 3.053 & 0.171 & 0.668 & 3.636 & 0.240 & 2.294 & 0.955 & 0.664 & 0.412 & 0.0000 \\
\hline 7 & 2.978 & 0.259 & 0.632 & 3.288 & 0.359 & 2.305 & 0.966 & 0.653 & NA & 0.0002 \\
\hline 8 & 2.978 & 0.340 & 0.599 & 3.615 & 0.466 & 2.292 & 0.953 & 0.666 & NA & 0.0011 \\
\hline 9 & 1.261 & 0.155 & 0.226 & 1.317 & 0.138 & 2.392 & 1.053 & 0.567 & 0.203 & 0.0000 \\
\hline 10 & 1.261 & 0.305 & 0.229 & 1.317 & 0.274 & 2.381 & 1.042 & 0.578 & 0.376 & 0.0000 \\
\hline 11 & 2.243 & 0.170 & 0.639 & 2.231 & 0.240 & 2.412 & 1.073 & 0.547 & 0.356 & 0.0000 \\
\hline 12 & 2.260 & 0.255 & 0.625 & 2.243 & 0.353 & 2.406 & 1.067 & 0.552 & 0.503 & 0.0000 \\
\hline 13 & 2.260 & 0.341 & 0.603 & 2.260 & 0.460 & 2.398 & 1.059 & 0.561 & NA & 0.0007 \\
\hline 14 & 2.956 & 0.173 & 0.660 & 3.252 & 0.247 & 2.402 & 1.063 & 0.557 & 0.475 & 0.0000 \\
\hline 15 & 2.941 & 0.258 & 0.635 & 3.252 & 0.364 & 2.395 & 1.055 & 0.564 & NA & 0.0006 \\
\hline 16 & 2.978 & 0.294 & 0.626 & 3.252 & 0.412 & 2.384 & 1.045 & 0.575 & NA & 0.0012 \\
\hline 17 & 1.250 & 0.157 & 0.297 & 1.281 & 0.139 & 2.496 & 1.157 & 0.462 & 0.238 & 0.0000 \\
\hline 18 & 1.250 & 0.235 & 0.272 & 1.317 & 0.208 & 2.489 & 1.150 & 0.470 & 0.310 & 0.0000 \\
\hline 19 & 1.259 & 0.305 & 0.256 & 1.320 & 0.272 & 2.500 & 1.161 & 0.459 & 0.389 & 0.0000 \\
\hline 20 & 2.210 & 0.138 & 0.636 & 2.210 & 0.192 & 2.493 & 1.154 & 0.465 & 0.304 & 0.0000 \\
\hline 21 & 2.222 & 0.202 & 0.634 & 2.188 & 0.280 & 2.482 & 1.143 & 0.476 & 0.433 & 0.0000 \\
\hline 22 & 2.210 & 0.274 & 0.628 & 2.210 & 0.374 & 2.499 & 1.160 & 0.460 & NA & 0.0005 \\
\hline 23 & 3.192 & 0.104 & 0.670 & 3.192 & 0.149 & 2.486 & 1.147 & 0.473 & 0.322 & 0.0000 \\
\hline $25^{\circ}$ & 3.147 & 0.175 & 0.664 & 3.192 & 0.250 & 2.490 & 1.151 & 0.468 & NA & 0.0001 \\
\hline 26 & 3.147 & 0.245 & 0.652 & 3.192 & 0.351 & 2.490 & 1.151 & 0.468 & NA & 0.0011 \\
\hline 27 & 1.259 & 0.261 & 0.268 & 1.320 & 0.232 & 2.498 & 1.159 & 0.461 & 0.334 & 0.0000 \\
\hline 28 & 1.259 & 0.305 & 0.267 & 1.320 & 0.270 & 2.498 & 1.159 & 0.460 & 0.359 & 0.0000 \\
\hline 29 & 2.188 & 0.201 & 0.608 & 2.188 & 0.277 & 2.498 & 1.159 & 0.461 & 0.431 & 0.0000 \\
\hline 30 & 2.188 & 0.285 & 0.615 & 2.188 & 0.390 & 2.494 & 1.155 & 0.464 & NA & $0: 0000$ \\
\hline 31 & 3.147 & 0.140 & 0.674 & 3.192 & 0.202 & 2.498 & 1.159 & 0.461 & 0.412 & 0.0000 \\
\hline 32 & 3.147 & 0.210 & 0.660 & 3.192 & 0.302 & 2.495 & 1.156 & 0.463 & NA & 0.0004 \\
\hline
\end{tabular}


Table 2

Wave Condition, Runup, and Overtopping Data for Tests with a $1: 3.5$ Slope

\begin{tabular}{|c|c|c|c|c|c|c|c|c|c|c|}
\hline $\begin{array}{l}\text { Test } \\
\text { No. }\end{array}$ & $\begin{array}{l}\text { Array } 1 \\
\text { Wave } \\
\text { Period } \\
\mathrm{T}_{\mathrm{p}}(1) \\
\text { sec } \\
\end{array}$ & $\begin{array}{l}\text { Array } 1 \\
\text { Wave } \\
\text { Height } \\
\mathrm{H}_{\text {mo }}(1) \\
\text { ft }\end{array}$ & $\begin{array}{l}\text { Array } 2 \\
\text { Reflection } \\
\text { Coefficient } \\
\mathrm{K}_{\mathrm{r}}(2) \\
\end{array}$ & $\begin{array}{l}\text { Array } 2 \\
\text { Wave } \\
\text { Period } \\
\mathrm{T}_{\mathrm{p}}(2) \\
\text { sec } \\
\end{array}$ & $\begin{array}{l}\text { Array } 2 \\
\text { Wave } \\
\text { Height } \\
\mathrm{H}_{\text {mo }}(2) \\
\text { ft }\end{array}$ & $\begin{array}{l}\text { Average } \\
\text { SwL } \\
\text { Depth } \\
\text { h } \\
\mathrm{ft}\end{array}$ & $\begin{array}{l}\text { Depth } \\
\text { at } \\
\text { Toe } \\
d_{s} \\
\text { ft }\end{array}$ & $\begin{array}{c}\text { Freeboard } \\
\text { F } \\
\mathrm{ft}\end{array}$ & $\begin{array}{l}\text { Upper } \\
\text { Limit of } \\
\text { Runup } \\
R_{\max } \\
\text { ft }\end{array}$ & $\begin{array}{c}\text { Overtopping } \\
\text { Rate } \\
Q \\
\text { cfs/ft }\end{array}$ \\
\hline 1 & 1.261 & 0.153 & 0.185 & 1.261 & 0.140 & 2.300 & 1.136 & 0.658 & 0.110 & 0.0000 \\
\hline 2 & 2.281 & 0.331 & 0.326 & 2.303 & 0.362 & 2.300 & 1.136 & 0.658 & 0.410 & 0.0000 \\
\hline 3 & 2.281 & 0.331 & 0.348 & 2.303 & 0.354 & 2.300 & 1.136 & 0.658 & 0.530 & 0.0000 \\
\hline 4 & 2.978 & 0.243 & 0.460 & 3.288 & 0.259 & 2.299 & 1.135 & 0.659 & 0.580 & 0.0000 \\
\hline 5 & 2.978 & 0.324 & 0.445 & 3.288 & 0.343 & 2.298 & 1.134 & 0.660 & NA & 0.0003 \\
\hline 6 & 1.261 & 0.229 & 0.107 & 1.317 & 0.204 & 2.400 & 1.236 & 0.558 & 0.242 & 0.0000 \\
\hline 7 & 1.261 & 0.301 & 0.238 & 1.317 & 0.229 & 2.400 & 1.236 & 0.558 & 0.250 & 0.0000 \\
\hline 8 & 2.260 & 0.245 & 0.363 & 2.260 & 0.268 & 2.400 & 1.236 & 0.558 & 0.420 & 0.0000 \\
\hline 9 & 2.260 & 0.329 & 0.352 & 2.281 & 0.361 & 2.400 & 1.236 & 0.558 & NA & 0.0001 \\
\hline 10 & 2.941 & 0.241 & 0.458 & 3.200 & 0.252 & 2.400 & 1.236 & 0.558 & $\mathrm{NA}$ & 0.0001 \\
\hline 11 & 2.941 & 0.322 & 0.442 & 3.175 & 0.334 & 2.395 & 1.231 & 0.563 & NA & 0.0012 \\
\hline 12 & 2.978 & 0.160 & 0.442 & 2.978 & 0.169 & 2.400 & 1.236 & 0.558 & 0.497 & 0.0000 \\
\hline 13 & 1.250 & 0.123 & 0.136 & 1.251 & 0.110 & 2.500 & 1.336 & 0.458 & 0.167 & 0.0000 \\
\hline 14 & 1.250 & 0.153 & 0.125 & 1.251 & 0.137 & 2.502 & 1.338 & 0.456 & 0.229 & 0.0000 \\
\hline 15 & 1.250 & 0.229 & 0.109 & 1.250 & 0.205 & 2.500 & 1.336 & 0.458 & 0.279 & 0.0000 \\
\hline 16 & 1.250 & 0.300 & 0.111 & 1.261 & 0.266 & 2.500 & 1.336 & 0.458 & 0.314 & 0.0000 \\
\hline 17 & 2.210 & 0.164 & 0.406 & 2.210 & 0.185 & 2.530 & 1.366 & 0.428 & 0.324 & 0.0000 \\
\hline 18 & 2.210 & 0.197 & 0.400 & 2.210 & 0.221 & 2.500 & 1.336 & 0.458 & 0.401 & 0.0000 \\
\hline 19 & 2.210 & 0.280 & 0.390 & 2.206 & 0.311 & 2.501 & 1.337 & 0.457 & NA & 0.0001 \\
\hline 20 & 2.210 & 0.328 & 0.380 & 2.206 & 0.364 & 2.497 & 1.333 & 0.461 & NA & 0.0005 \\
\hline 21 & 2.941 & 0.191 & 0.469 & 3.133 & 0.200 & 2.510 & 1.346 & 0.448 & $\mathrm{NA}$ & 0.0000 \\
\hline 22 & 2.941 & 0.240 & 0.467 & 3.133 & 0.249 & 2.497 & 1.333 & 0.462 & $\mathrm{NA}$ & 0.0006 \\
\hline 23 & 2.941 & 0.273 & 0.472 & 3.133 & 0.282 & 2.500 & 1.336 & 0.458 & $\mathrm{NA}$ & 0.0014 \\
\hline
\end{tabular}


Table 3

Overtopping Data From Physical Model Tests

\begin{tabular}{|c|c|c|c|c|c|c|c|c|c|}
\hline & $\begin{array}{c}\text { Cotan } \\
\text { Structure }\end{array}$ & $\begin{array}{l}\text { Array } 2 \\
\text { Wave } \\
\text { Period }\end{array}$ & $\begin{array}{l}\text { Array } 2 \\
\text { Wave } \\
\text { Height }\end{array}$ & $\begin{array}{c}\text { Average } \\
\text { SWL } \\
\text { Depth }\end{array}$ & $\begin{array}{l}\text { Depth } \\
\text { at } \\
\text { Toe }\end{array}$ & Freeboard & $\begin{array}{c}\text { Overtopping } \\
\text { Rate }\end{array}$ & \multicolumn{2}{|c|}{ Dimensionless } \\
\hline $\begin{array}{l}\text { Test } \\
\text { No. }\end{array}$ & $\begin{array}{l}\text { S1ope } \\
\mathrm{m}\end{array}$ & $\begin{array}{l}\mathrm{T}_{\mathrm{p}}(2) \\
\sec \end{array}$ & $\begin{array}{c}\mathrm{H}_{\mathrm{mo}}(2) \\
\mathrm{ft}\end{array}$ & $\begin{array}{l}\mathrm{h} \\
\mathrm{Et}\end{array}$ & $\begin{array}{l}d_{s} \\
f t\end{array}$ & $\begin{array}{l}F \\
f t\end{array}$ & $\begin{array}{c}Q \\
\mathrm{cfs} / \mathrm{ft}\end{array}$ & $\begin{array}{c}\text { Freeboard } \\
\text { F' }^{\prime}\end{array}$ & Overtopping \\
\hline 4 & 2 & 3.615 & 0.462 & 2.292 & 0.953 & 0.667 & 0.001077 & 0.274741 & 0.000603 \\
\hline 5 & 2 & 2.299 & 0.463 & 2.296 & 0.957 & 0.662 & 0.000172 & 0.368713 & 0.000096 \\
\hline 7 & 2 & 3.288 & 0.359 & 2.305 & 0.966 & 0.653 & 0.000174 & 0.339200 & 0.000142 \\
\hline 8 & 2 & 3.615 & 0.466 & 2.292 & 0.953 & 0.666 & 0.001138 & 0.273275 & 0.000631 \\
\hline 13 & 2 & 2.260 & 0.460 & 2.398 & 1.059 & 0.561 & 0.000671 & 0.317160 & 0.000379 \\
\hline 15 & 2 & 3.252 & 0.364 & 2.395 & 1.055 & 0.564 & 0.000600 & 0.292272 & 0.000481 \\
\hline 16 & 2 & 3.252 & 0.412 & 2.384 & 1.045 & 0.575 & 0.001237 & 0.274406 & 0.000824 \\
\hline 22 & 2 & 2.210 & 0.374 & 2.499 & 1.160 & 0.460 & 0.000487 & 0.303019 & 0.000375 \\
\hline 25 & 2 & 3.192 & 0.250 & 2.490 & 1.151 & 0.468 & 0.000062 & 0.315511 & 0.000087 \\
\hline 26 & 2 & 3.192 & 0.351 & 2.490 & 1.151 & 0.468 & 0.001050 & 0.252046 & 0.000890 \\
\hline 29 & 2 & 2.188 & 0.277 & 2.498 & 1.159 & 0.461 & 0.000017 & 0.373098 & 0.000020 \\
\hline 30 & 2 & 2.188 & 0.390 & 2.494 & 1.155 & 0.464 & 0.000015 & 0.299274 & 0.000010 \\
\hline 32 & 2 & 3.192 & 0.302 & 2.495 & 1.156 & 0.463 & 0.000400 & 0.275367 & 0.000424 \\
\hline 4 & 3.5 & 3.288 & 0.259 & 2.299 & 1.135 & 0.659 & 0.000012 & 0.426341 & 0.000016 \\
\hline 5 & 3.5 & 3.288 & 0.343 & 2.298 & 1.134 & 0.660 & 0.000321 & 0.353749 & 0.000281 \\
\hline 9 & 3.5 & 2.281 & 0.361 & 2.400 & 1.236 & 0.558 & 0.000061 & 0.368602 & 0.000049 \\
\hline 10 & 3.5 & 3.200 & 0.252 & 2.400 & 1.236 & 0.558 & 0.000148 & 0.374088 & 0.000206 \\
\hline 11 & 3.5 & 3.175 & 0.334 & 2.395 & 1.231 & 0.563 & 0.001234 & 0.314373 & 0.001127 \\
\hline 19 & 3.5 & 2.206 & 0.311 & 2.501 & 1.337 & 0.457 & 0.000086 & 0.341318 & 0.000087 \\
\hline 20 & 3.5 & 2.206 & 0.364 & 2.497 & 1.333 & 0.461 & 0.000490 & 0.309814 & 0.000393 \\
\hline 21 & 3.5 & 3.133 & 0.200 & 2.510 & 1.346 & 0.448 & 0.000033 & 0.354958 & 0.000065 \\
\hline 22 & 3.5 & 3.133 & 0.249 & 2.497 & 1.333 & 0.462 & 0.000589 & 0.315820 & 0.000833 \\
\hline 23 & 3.5 & 3.133 & 0.282 & 2.500 & 1.336 & 0.458 & 0.001409 & 0.288780 & 0.001657 \\
\hline
\end{tabular}


effective, as it accounts for different water levels in the freeboard, wave heights in $\mathrm{H}_{\mathrm{mo}}$, and wave periods in $\mathrm{L}_{0}$.

14. The overtopping rate was nondimensionalized by

$$
Q^{\prime}=\frac{Q}{\left(g H_{\mathrm{mo}}^{3}\right)^{1 / 2}}
$$

where $Q^{\prime}$ is the dimensionless overtopping rate per unit length of structure, $Q$ is the overtopping rate per unit length of structure, and $g$ is gravitational acceleration.

15. Figure 3 plots dimensionless overtopping rates versus relative freeboard. Although some scatter in the data is evident, it is clear that there is a direct relationship between the two parameters for each slope tested. A simple equation of the form

$$
Q^{\prime}=C_{0}\left[\exp \left(C_{1} * F^{\prime}\right)\right]\left[\exp \left(C_{2} * m\right)\right]
$$

where $C_{0}, C_{1}$, and $C_{2}$ are dimensionless regression coefficients and $m$ is the cotangent of structure slope with the horizontal, was found to describe the relationship reasonably well. However, scatter in the data indicated that design based on a "best fit" curve would be inappropriate, as measured overtopping would exceed predicted overtopping much of the time. Instead, it was desired to fit a curve through the larger overtopping values as shown in Figure 3. The curve illustrated was obtained from Equation 6 by ignoring three data points from the $1: 2$ tests and four data points from the $1: 3.5$ tests, indicated in Figure 3 by a solid dot next to the data point. Values of the regression coefficients are

$$
\begin{aligned}
& C_{0}=0.457847 \\
& C_{1}=-29.4467 \\
& C_{2}=0.846428
\end{aligned}
$$

Although this equation is remarkably simple and easy to use, it fits the remaining data points with a coefficient of multiple determination $\left(R^{2}\right)$ of nearly 0.91

16. Although some conservatism is built into the coefficients given above by ignoring some of the lower overtopping values, it is clear that in 


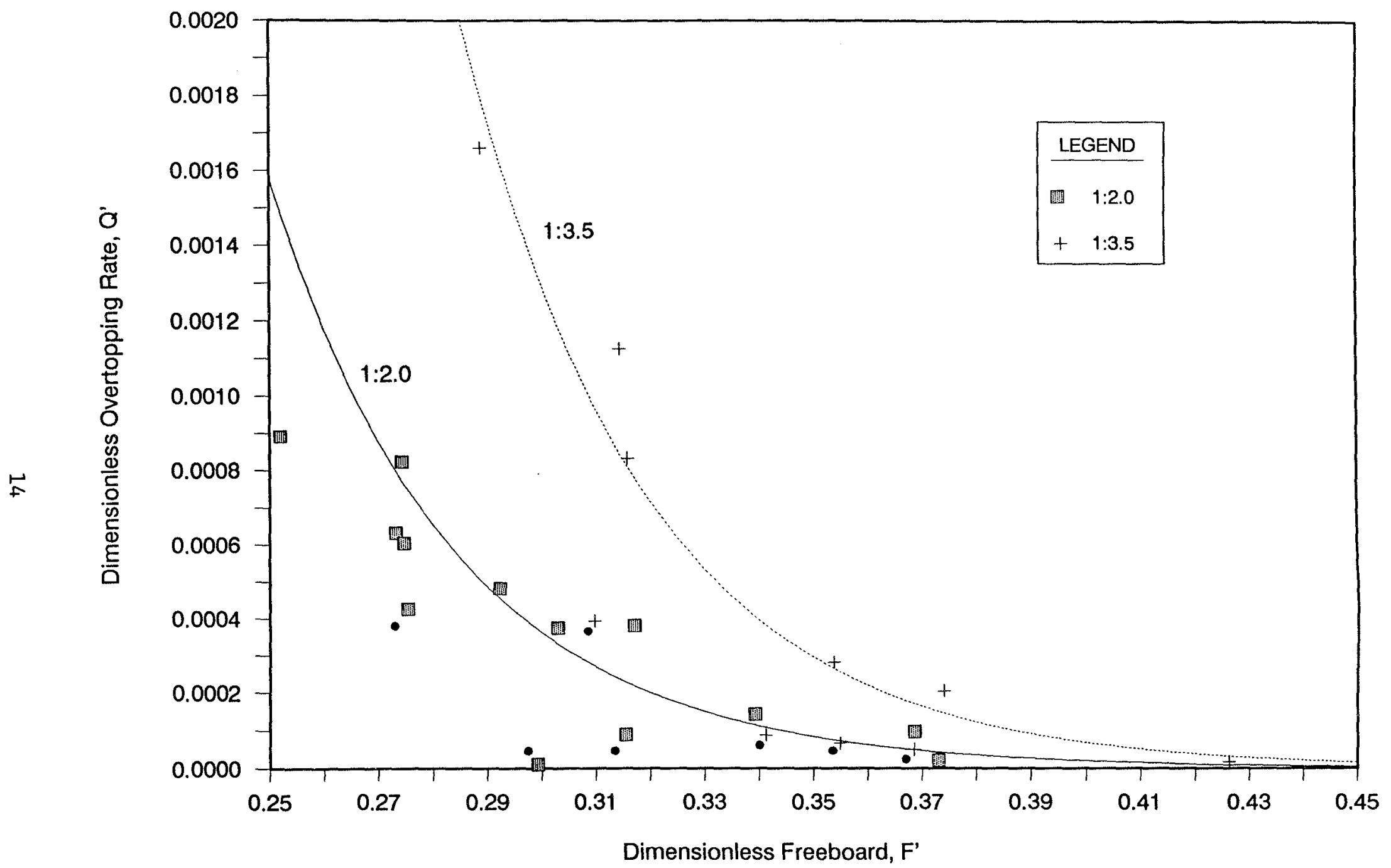

Figure 3. Dimensionless overtopping rate as a function of dimensionless freeboard and structure slope. Data points marked by a dot were not used in regression analysis 
some cases measured overtopping was still slightly higher than predicted values. These coefficients for Equation 6 are therefore considered to be optimum values for design.

17. Conditions tested in the wave flume included dimensionless freeboards in the range

$$
0.25<\mathrm{F}^{\prime}<0.43
$$

and structure slopes of $1: 2$ and $1: 3.5$. The overtopping equation presented here (Equation 6) should not be applied outside these ranges. For conditions outside these ranges, or where overtopping may cause substantial damage, physical model testing is recommended. An example problem is given in Appendix A.

\section{Conclusions}

18. An equation is presented that predicts overtopping rates on a riprap revetment over an impermeable substrate for a range of water levels, wave heights and periods, and structure slopes. Within these ranges, the equation accurately predicts the higher overtopping values observed in physical model tests with irregular waves. 


\section{References}

Ahrens, J. P., and Heimbaugh, M. S. 1988. "Seawall Overtopping Model," Proceedings, 21 st Coastal Engineering Conference, Malaga, Spain.

Automated Coastal Engineering System. 1990. Vers. 1.06, US Army Engineer Waterways Experiment Station, Coastal Engineering Research Center, Vicksburg, MS .

Fukudo, N., Uno, T., and Irie, I. 1974. "Field Observations of Wave Overtopping of Wave Absorbing Revetment," Coastal Engineering in Japan. Vol 17.

Goda, Y. 1985. Random Seas and the Design of Maritime Structures, University of Tokyo Press, Tokyo, Japan.

Hudson, R. Y., and Jackson, R. A. 1962. "Design of Riprap Cover Layers for Railroad Relocation Fills, Ice Harbor and John Day Lock and Dam Projects; Hydraulic Model Investigation," Miscellaneous Paper 2-465, US Army Engineer Waterways Experiment Station, Vicksburg, MS.

Shore Protection Manual. 1984. 4th ed., 2 vols, US Army Engineer Waterways Experiment Station, Coastal Engineering Research Center, US Government Printing Office, Washington, DC.

Tsuruta, S., and Goda, Y. 1968. "Expected Discharge of Irregular Wave Overtopping," Proceedings, 11th Coastal Engineering Conference, London, England.

Wegge1, J.R. 1976. "Wave Overtopping Equation," Proceedings, 15th Coastal Engineering Conference, Honolulu, HI. 


\section{Appendix A: Example Problem}

GIVEN: A riprap revetment is built on a $1: 2$ slope. It is estimated that under storm conditions of $H_{m o}=8 \mathrm{ft}$ and $T_{p}=10 \mathrm{sec}\left(T_{p}=\right.$ wave period of peak energy density), storm surge and setup will reduce the freeboard to $9 \mathrm{ft}$.

FIND: Determine the overtopping rate per foot of revetment length under the given storm conditions.

SOLUTION: The deepwater unrefracted wavelength $L_{0}$ is determined from the wave period as

$$
\begin{gathered}
L_{o}=\frac{g}{2 \pi} T_{p}^{2} \\
L_{0}=\left(\frac{32.2 \mathrm{ft} / \mathrm{sec}^{2}}{6.28}\right) 100 \mathrm{sec}^{2}=512 \mathrm{ft}
\end{gathered}
$$

Relative freeboard is determined by Equation 4 in the main text.

$$
F^{\prime}=\frac{9 f t}{[(8 f t)(8 f t)(512 f t)]^{1 / 3}}=0.281
$$

Both structure slope and relative freeboard are within the ranges tested in the the wave flume. Therefore, the dimensionless overtopping rate can be determined by Equation 6 in the main text.

$$
Q^{\prime}=[0.457847][\exp (-29.4467)(0.281)][\exp (0.846428)(2)]=0.000634
$$

The overtopping rate is determined by rearranging Equation 5 in the main text.

$$
\begin{gathered}
Q=Q^{\prime}\left(\mathrm{gH}_{\mathrm{mo}}{ }^{3}\right)^{1 / 2} \\
Q=0.000634\left\{\left[32.2 \mathrm{ft} / \mathrm{sec}^{2}\right]\left[(8 \mathrm{ft})^{3}\right]\right\}^{1 / 2}=0.081 \mathrm{cfs} / \mathrm{ft}
\end{gathered}
$$

This is equal to more than $2,000 \mathrm{gal} / \mathrm{hr}$ per foot of revetment. As a reference, Fukuda, Uno, and Irie (1974)* measured and filmed overtopping of a

* See References at the end of the main text. 
revetment and bulkhead during storm conditions, and then showed the films to a panel of coastal experts to determine the danger presented by the overtopping. Average results of the panel indicated that an overtopping rate of $0.02 \mathrm{cfs} / \mathrm{ft}$ was dangerous for a person walking $30 \mathrm{ft}$ behind the bulkhead, and a rate of $0.002 \mathrm{cfs} / \mathrm{ft}$ was dangerous immediately behind the bulkhead. Goda (1985) estimated the maximum overtopping rate that an unpaved coastal revetment can sustain without damage to be about $0.5 \mathrm{cfs} / \mathrm{ft}$. 


\section{Appendix B: Notation}

\begin{tabular}{|c|c|}
\hline $\mathrm{C}_{0}$ & Regression coefficient \\
\hline$C_{1}$ & Regression coefficient \\
\hline $\mathrm{C}_{2}$ & Regression coefficient \\
\hline $\mathrm{D}_{85}$ & Diameter of 85 percent of stone \\
\hline $\mathrm{D}_{15}$ & Diameter of 15 percent of stone \\
\hline$\left(D_{n}\right)_{50}$ & Nominal diameter of stone \\
\hline$F$ & Dimensionless freeboard \\
\hline$F^{\prime}$ & Relative freeboard \\
\hline g & Gravitational acceleration \\
\hline $\mathrm{H}$ & Design wave height \\
\hline $\mathrm{H}_{\mathrm{mo}}$ & Wave height of the zeroth moment \\
\hline $\mathrm{H}_{\mathrm{s}}$ & Significant wave height \\
\hline $\mathrm{H}_{10}$ & Highest 10 percent wave height \\
\hline $\mathrm{K}_{\mathrm{RR}}$ & Graded stone stability coefficient \\
\hline $\mathrm{L}_{\circ}$ & Deepwater Airy wavelength \\
\hline $\mathrm{m}$ & $\begin{array}{l}\text { Slope of the structure (cotangent of structure slope with the } \\
\text { horizontal) }\end{array}$ \\
\hline $\mathrm{Q}$ & Dimensional overtopping rate per unit length of seawall \\
\hline$Q^{\prime}$ & Dimensionless overtopping rate \\
\hline $\mathrm{R}^{2}$ & Coefficient of multiple determination \\
\hline$S_{r}$ & $\begin{array}{l}\text { Specific gravity of an individual stone relative to the water in } \\
\text { which the breakwater is constructed }\end{array}$ \\
\hline $\mathrm{T}_{\mathrm{p}}$ & Wave period of peak energy density \\
\hline$w_{r}$ & Unit weight of rock \\
\hline$w_{w}$ & Specific weight of water, pcf \\
\hline W & Weight of an individual stone \\
\hline$W_{50}$ & Median stone weight \\
\hline$\theta$ & Angle of structure slope, degrees \\
\hline
\end{tabular}

